\title{
Death and Pollution as a Common Matrix of Japanese Buddhism and Shintō
}

Starting from two famous examples of death taboos in sources from the seventh and tenth centuries, respectively, this article argues that the Japanese taboos regarding pollution (kegare), which have become intimately associated with Shintō, are actually a product of different cultural influences and came into being only at a time when worship of Buddhist and local deities (kami) already existed side by side. My focus, however, is not the question when and where such taboos originated, but why they were sustained during many centuries which were dominated by a Buddhist world view. My conclusion is that the concept of kegare, and by extension the deities who defined what was pure and what was defiled, became an important means to single out Buddhist clerics as specialists dealing with death and the ensuing pollution. Kegare, therefore, served as a non-Buddhist concept for the benefit of Buddhism. To back up this argument, the article contains several examples from literary sources which provide insights into the interactions between daily life at court and the pantheon in Japan's premodern period.

Fears and taboos related to death pollution are a pervasive motif in Japanese cultural history and are often regarded as a salient feature of Japan's "native religion", Shintō. Traditional scholarship in Japan as well as in the West explained such fears as a transhistorical phenomenon and as a major reason why Shintō retains its importance in Japan despite the undeniable success of Buddhism in the country. Indeed, the concept of "pollution" or "defilement" (kegare) can be seen as one of the main constituents of Shintō as we know it today. It could even be argued that avoiding kegare and maintaining purity is what Shintō is all about. The most important rituals of Shintō are purification rites called harae, lit. "to sweep away." Death, however, is seen as such a dangerous source of pollution that Shintō cannot deal with it directly. Shintō priests, therefore, usually refrain from all death-related rituals and pay particular attention to avoid pollution during funerals, in graveyards, and other places or events related to death. Buddhism, on the other hand, has monopolised the realm of death rituals since at least the beginning of the medieval period (twelfth-sixteenth centuries). Its specialisation on religious services for the dead went so far that Japanese Buddhism is sometimes labelled "funeral Buddhism" (sōshiki bukkyō) especially in regard to the early modern period (seventeenth-nineteenth centuries). In other words, Japanese religion established a clear division of labor, according to which Buddhism deals with death and the afterlife, while Shintō deals with life and this-worldly concerns. While there is a general consensus on this

¿ Open Access. (๑) 2020 Bernhard Scheid, published by De Gruyter. @) BY-NC-ND This work is licensed under the Creative Commons Attribution-NonCommercial-NoDerivatives 4.0 License.

https://doi.org/10.1515/9783110597745-022 
state of affairs amongst most specialists of Japanese religious history, opinions are divided as to the reasons and origins of this apparently peaceful cooperation.

A fundamental critique of the transhistorical connection between Shintō and death taboos appeared in 1979 in the form of a small volume called Shintō no seiritsu (“The Formation of Shintō") ${ }^{1}$ by Takatori Masao (1926-1981), a historian with a particular interest in Japanese folklore. Takatori argued that the death taboos of Shintō can only function if there is another religion that provides ways of dealing with the dying and the dead, burial and mourning rituals. The death taboo as it appears in sources of the classical period (eighth to twelfth centuries CE, see below) and later could therefore not have existed before the establishment of Japanese Buddhism in the sixth and seventh centuries. Drawing from classical texts as well as from ethnographic sources, Takatori supported his argument with empirical data and demonstrated that death taboos were not as firmly rooted in "folk religion" as had hitherto been generally assumed. While Takatori did not deny the connection between Shintō and fears of pollution in later periods, he argued that both took shape as a by-product of the establishment of the classical central state between the seventh and ninth centuries. This hypothesis was arguably the beginning of a deconstruction of the received concept of Shintō, a deconstruction that was taken up by scholars such as Kuroda Toshio (1926-1993) ${ }^{2}$ and continues to have an impact on Shintō scholarship both in Japan and the West up to the present day. ${ }^{3}$ Drawing on this line of inquiry, this paper will examine some key examples of the impact of death taboos, especially in the period of classical court culture. My conclusion will focus on the question why taboos related to death, in spite of their apparent non-Buddhist nature, have survived almost one and a half millennia of Buddhist impact on Japanese religious culture.

1 Takatori, Shintō no seiritsu ("The Formation of Shintō").

2 Kuroda, "Shinto in the History of Japanese Religion," 1-21.

3 Recent works by Western scholars that attempt to revise the received image of Shintō include Breen and Teeuwen, eds., Shinto in History; Teeuwen and Scheid, eds., Tracing Shinto in the History of Kami Worship; Teeuwen and Rambelli, eds., Buddhas and Kami in Japan; Faure, Como, Nobumi, eds., Rethinking Medieval Shintō; Ooms, Imperial Politics and Symbolics in Ancient Japan, to name but a few. Most of these authors agree that the term "Shintō" is fraught with problems when applied to the early phases of Japanese religious history, because the concept of a native religion hardly existed and the term shintō was not in common use at the time (see esp. Kuroda, "Shinto in the History of Japanese Religion," and Teeuwen and Scheid, Tracing Shinto in the History of Kami Worship). Therefore, "ritualism for the kami (native deities)" might be a more appropriate term. For the sake of simplicity, however, I am nevertheless using terms like "Shintō", "Shintō priest", or "Shintō shrine" when referring to the ritual system, the ritualists, and the structures of the kami-deities. 


\section{Contrasting Examples, 7th and 10th Centuries}

In the second half of the seventh century, Japan adopted the legal code of Tang $\mathrm{China}^{4}$ and on this new legal basis established a centralised state. The ensuing process of Japanese "self-Sinicisation", which included the establishment of a permanent capital and the elevation of the ruler to a "heavenly sovereign" (tennō), is comparable in its dimensions to Japan's rapid modernisation/Westernisation in the aftermath of the Meiji Restoration (1868). In order to demonstrate the radical shift in religious values that occurred at that time, I would like to cite two particularly striking examples to which Takatori Masao first drew our attention. ${ }^{5}$

The first example dates from the year 642, and thus from shortly before the Taika Reforms of 645 that ushered in the Japanese adoption of the Chinese legal system. The Nihon shoki, the first official Japanese chronicle, written in 720, relates a story about a Korean envoy who has been sent to the Japanese court together with his wife and their child. During his stay in Japan, the child dies and is buried in Japanese soil. The envoy and his wife, however, avoid any contact with the dead body and stay away from the child's funeral. The text comments:

It is the general custom in Baekje and Silla (= Korea, B. S.) when a death occurs that even the parents, brothers, husband and wife, and sisters of the deceased should never look on [the dead] again. Judging from this, they are utterly wanting in feeling, and not to be distinguished from birds and beasts. ${ }^{6}$

Clearly, at this time the Korean envoy's particular taboo avoidances in the face of death were seen as an unnatural foreign custom.

The second example dates from about 300 years later and takes place in the mid-Heian (ninth-twelfth centuries) period, at the apex of classical Japanese court culture. It concerns the death of an imperial consort, Fujiwara no Anshi (also called Yasuko, 927-964), who died at the age of 37 after giving birth to her tenth child with Emperor Murakami (926-967, r. 946-967). In this case, we are much better informed about the specific circumstances because of the existence of a number of different sources, including the Eiga monogatari ("Tales of Fame and Fortune"). ${ }^{7}$ From

4 The laws are generally known in Japanese as ritsu-ryo, "penal and administrative laws". They are also known by the names of subsequent redactions, the only extant one being the Yōrō code, drafted in 718 and enacted in 757, which will be discussed below.

5 Takatori, Shintō no seiritsu, chap. 4.

6 Nihon shoki, 24 (Kōkyoku Tennō), 642CE/5/22; Nihongi: Chronicles of Japan from the Earliest Times to A.D. 697, trans. by Aston, vol. 2, 173-174 (with minor modifications); Takatori, Shintō no seiritsu, 240-241.

7 The Eiga monogatari is a historical account of Heian court life compiled from the diaries of various court ladies in the 11th century. It starts with the reign of Emperor Uda (867-931, r. 887-897) and concentrates on the fortunes of the Fujiwara House and in particular on Fujiwara no Michinaga (966-1028). For Takatori's treatment of Anshi's death, which includes other sources as well, see Takatori, Shintō no seiritsu, 20-22 and 223. 
its account we learn that, although the emperor was extremely concerned about the fate of his main consort and her child, from the moment she fell ill it was impossible for him to get in touch with her in person. In fact, Anshi moved to the estates of her maternal family several months before the expected birth of her child, and it was there that she gave birth. General custom at that time treated child birth as a source of pollution similar to death (as we will discuss in more detail below). Therefore, no birth was permitted to take place in the emperor's residence, which had to be kept free from any form of defilement. In the case of Anshi, other reasons added to this general pattern of avoidance. According to the Eiga monogatari, she had been ill since the beginning of her pregnancy and was herself very well aware that her illness was caused by the death spirits of former adversaries. ${ }^{8}$ In particular, she was tormented by the spirit of a distant uncle whose daughter was herself a member of the emperor's harem. The latter had borne a son to the emperor before Anshi, but Anshi and her family had successfully arranged for Anshi's oldest son to be elected crown prince. Such decisions were of utmost importance to the entire political elite, since it was an established practice during most of the Heian period that a maternal relative of the reigning monarch acted as imperial regent (sesshō kanpaku). Monarchs came under increasing pressure to step down from their leading position as soon as they reached a mature age. Both monarchs and crown princes, therefore, were usually quite young and de facto political vehicles for their maternal uncles and grandfathers. As many other legends from the Heian period confirm, successful lobbying for a particular imperial successor could later lead to troubles with the spirits of defeated enemies, particularly if these enemies were murdered or died in exile in the course of political machinations.

Anshi bravely endured the consequences of her political success. When she realised that the vengeful spirit of her uncle had taken possession of her, she isolated herself not only from the emperor but also from her children in order to avoid spiritual contagion. The emperor in turn kept sending messengers asking about her health, as well as numerous Buddhist clerics who conducted exorcist rites in close vicinity to her private rooms:

Finally the pains of approaching childbirth added to Empress Anshi's misery. The necessary preparations took place, and the assembled monks set up a tremendous chanting of sutras. Anshi seemed alarmingly close to death. It was not even certain that she was still breathing. The throng of people in the chamber and its vicinity all joined in frantic supplications to the gods and buddhas, and presently, to their great delight, a baby's cry was heard. Then there was a commotion about the afterbirth, but in the midst of it all Anshi's spirit fled. It was the Twenty-ninth of the Fourth Month in the fourth year of Ōwa [964]. Words cannot describe such an event. ${ }^{9}$

8 As Michel Strickmann has argued, such beliefs were based on what he calls the "Tantric revolution" in China and Japan (Strickmann, Chinese Magical Medicine, chapter 5: "The Genealogy of Spirit Possession"). 
After this dramatic climax, the story ends with the description of Anshi's sumptuous funeral rites. While in this case Anshi's children were allowed to take part, the emperor was not able to do so owing to his purified status. Instead, he "kept to a strict regimen of ritual purity, refusing to receive any of the consorts in his bedchamber, even for a few moments of harmless amusement, and abandoning all his customary pursuits so that he might engage in pious works on Anshi's behalf". ${ }^{10}$ At the end of the mourning period, however, the emperor turned to a lady with whom he had secretly been in love for a long time and made her his chief consort. ${ }^{11}$

Both of the examples cited relate the death of a family member, of a child and a mother, respectively. In both cases, their relatives must stay away from the deceased due to fears of defilement. In the first case, however, such fears and their related customs are condemned as a deficit of human feeling. In the second case, on the other hand, such fears seem so natural that the text hardly bothers to explain them in detail. Between the lines, however, it becomes clear that the fears relate to the world of the unseen, which is peopled with all sorts of malicious spirits. Such spirits are like pathogenic germs (to use a modern simile), and defilement creates conditions favorable for them. Indeed, it has been argued that diseases caused by the establishment of a capital city (8th century) and the ensuing urbanisation may be one reason for the emphasis placed on symbolic purity and the fear of defilement in the subsequent centuries. ${ }^{12}$

Putting aside the discussion of possible reasons, the two contrasting examples of handling death allow us to infer that fears of death pollution must have increased dramatically between the seventh and the tenth centuries, giving rise to a large number of rites of avoidance and purification. Indeed, around the time when the abovecited Tales of Fame and Fortunes were written, a leading courtier even noted in his diary that the fear of pollution represented a distinctively Japanese concern that did

9 Eiga monogatari, 1, translation: A Tale of Flowering Fortunes, trans. McCullough and Craig McCullough, 85.

10 A Tale of Flowering Fortunes, trans. McCullough and Craig McCullough, 87.

11 A Tale of Flowering Fortunes, trans. McCullough and Craig McCullough, 88-89. Anshi's children did make it to the throne, but her eldest son, Emperor Reizei (950-1011, r. 967-969), abdicated after two years, tortured by the same ghost as his mother, according to the Eiga monogatari. His younger brother, En'yū Tennō (959-991, r. 969-984), followed him to the throne while still a child.

12 Ooms, Imperial Politics and Symbolics in Ancient Japan, chap. 9, "Spirits”. William Farris, a leading expert on premodern Japanese demography, summarises the scope and impact of diseases as follows: "[...] beginning around 730 repeated outbreaks of lethal epidemics cut deeply into a population that often had no previous experience with a particular pathogen. The result was massive die-offs - as much as 25-35 percent approximately each generation. This basic pattern - a population with little or no immunity decimated by a deadly virus or bacterium every generation - continued unabated until 1150 [...] Effects were apparent in myriad aspects of culture, even religion and art.” (Farris, Japan's Medieval Population, 9; see also Farris, Population, Disease, and Land in Early Japan.) 
not exist in China and India. ${ }^{13}$ Nothing could be farther away from the evaluation of foreign customs of death avoidance by Japanese chroniclers 300 years earlier.

\section{The Codification of Taboos}

As Herman Ooms has argued, the preoccupation with purity and defilement may be traced back to the reign of Emperor Tenmu (631-686, r. 672-686), probably the single most influential ruler during the above-mentioned period of Sinicisation. ${ }^{14}$ According to Ooms, the concern with purity was not an essential feature of Japanese mentality but was introduced as a result of the social elites' emulation of continental practices. As elsewhere in East Asia, the opposition of pure and defiled served as a powerful metaphor to strengthen social stratification, ranging from the emperor as the apex of purity down to the strata of slaves and outcasts, who were identified with defilement. ${ }^{15}$

While Japanese chroniclers of the Nihon shoki had not yet fully adopted the purity paradigm and therefore exhibited some reservations regarding excessive taboos of death (as in the example of the Korean envoy), juridical texts of the same period prepared the ground for the taboos' inclusion into elite culture. The Japanese Yōrō code (eight century), for instance, mentions quite a few rules of abstinence, in particular in relation to annual ceremonies for the native kami at court. These rules include a definition of abstinence ${ }^{16}$ that clearly identifies matters related to death with ritual defilement:

Abstinence is defined as no mourning, no visits to the sick, no eating of meat, no death verdicts or execution of punishments, no music, and no contact with impurity. ${ }^{17}$

These rules generally follow the outline of the Chinese Tang code. ${ }^{18}$ However, Japanese laws on religious matters differed from China's in one decisive point: the

13 Fujiwara no Sanesuke (957-1046), Shōyūki, Manju 4 (1027 CE)/8/25; cited from Stone, "Do Kami Ever Overlook Pollution?," 205.

14 "The Tenmu dynasty witnessed the beginnings of a social appreciation of the purity-impurity pair without, however, reaching the level of intensity it acquired centuries later." (Ooms, Imperial Politics and Symbolics in Ancient Japan, 261). On Chinese precedence, see in particular 254-256.

15 Ooms, Imperial Politics and Symbolics in Ancient Japan, chapter 10 ("Purity").

16 Jap. imi or mono'imi; in the present example, the law refers to "partial abstinence" (ara'imi) in contrast to strict abstinence (ma'imi).

17 Yōrō ritsuryō, jingi ryō (laws relating to kami worship) §11, ed. Dettmer; transl. from Mori, “Ancient and Classical Japan," 37; for a more technical translation into German, see Dettmer, Der YōrōKodex. Die Gebote, 8-9.

18 It has been pointed out that some taboos in the Tang code may actually reflect Buddhist influences, especially meat eating taboos, which were originally an Indian practice. See, for instance, Strickmann, Chinese Magical Medicine. 
most prominent native deities were defined - in accordance with the official mythology - as ancestors of the ruling house, and the emperor himself was seen as a "manifest deity". ${ }^{19}$ This may be one reason why Japanese laws on purity and taboo were in many cases more detailed and more severe than their Chinese counterparts. ${ }^{20}$ Two centuries after the introduction of the legal code, rules on purity were formulated in even greater detail in the Engishiki ("Procedures of the Engi Era", 927), a legal document on court ritual today seen as one of the canonical texts of Shintō. It includes a list of abstinence rules, from which I would like to cite the following items: $:^{21}$

(item 1) At all times, if there is contact with defilement or evil, avoidance is practiced: for 30 days' time after the death of a person (counting from the day of burial), for 7 days after a birth, for 6 days after the death of a domestic animal, for 3 days after the birth of one (avoidance does not apply to chickens) [...].

This item establishes a certain hierarchy of polluting events. Human deaths are more defiling than human births, which in turn are more defiling than animal deaths or births. In contrast to the prescribed times of abstinence, the concrete forms of the ascetic practices required seem to have differed according to function and rank, but may have included - in addition to the above-mentioned provisions from the Yōrō code - refraining from sexual contacts. ${ }^{22}$

(item 2) At all times, when consoling in a bereavement, or calling upon the sick, or when reaching a place where a mound is being built, or encountering a 37th-day Buddhist memorial service, even though one's person is not defiled one is not allowed to enter the Imperial Palace on that day.

In other words, any contact with death or sickness, whether intentional or accidental, should cause people to refrain from entering the palace.

(item 6) At all times, if place A becomes defiled, person B who enters there (that is, takes a seat there) and all persons in that place become defiled. If C enters B's premises, his body alone becomes defiled, not those of people on his own premises. If D enters C's premises he does not become defiled.

This item indicates that pollution is contagious like a disease (even if its transmission ends after more than three instances). Items 2 and 6 make clear why the impe-

19 "In imperial edicts, the phrase 'The emperor who rules as a resplendent kami' is to be used." (Yōrō ritsuryō, Kushiki-ryō [public documents] §1, ed. Dettmer; Mori, "Ancient and Classical Japan,” 38.)

20 Ooms, Imperial Politics and Symbolics in Ancient Japan, 257.

21 The following four quotations are from Engishiki, book 3; the translation follows Engi-Shiki: Procedures of the Engi Era, trans. Bock, 116-117, with small modifications.

22 Ooms, Imperial Politics and Symbolics in Ancient Japan, 253, 256-257. 
rial consort Anshi had to avoid contact with family members in order to protect them from contagion by the evil spirit who had taken possession of her.

(item 4) At all times, during the days of partial abstinence before and after the festivals of Toshigoi, Kamo, Tsukinami, Kanname and Niiname, monks, nuns and persons in mourning, as well as bands of robbers, may not enter the Imperial Palace [...].

This item relates to state ceremonies by the emperor and high-ranking court priests that focused on offerings to the kami deities. The provision makes clear that not only people in mourning but also Buddhist clerics and (the punishment of captured) criminals can cause defilement. Such defilement would not only render the offerings ineffective but could enrage the kami, which could ultimately lead to natural catastrophes and epidemics.

The mention of (Buddhist) monks and nuns indicates the implicit identification of Buddhism with death pollution. This is apparent in other passages from the Engishiki, as well. The work contains, for instance, regulations for the imperial ancestor shrines in Ise, which rivalled the imperial palace in terms of purity. Among the most striking examples of dangers to the purity of Ise to be averted is a list of words that within the shrine's precincts have to be replaced by code words:

The inner seven words are: the Buddha is the 'Central One', the sutras are 'dyed paper', a
pagoda is a 'yew-tree', a temple is a 'tiled roof', a monk is 'long-hair', a nun is a 'female long-
hair', a Buddhist meal is 'short rations'.
Besides these there are the outer seven words: death is called 'getting well', illness is 'slum-
ber', weeping is 'shedding brine', blood is 'sweat', to strike is 'to caress', meat is 'mushrooms',
a tomb is a 'clod of earth'. ${ }^{23}$

This list systematically refers to Buddhism, on the one hand, and to potentially defiling functions of the human body. Both topics must not be referred to directly and related terms are at times even turned into their opposites ("long-hair" for monk, "getting well” for death).

Earlier scholars regarded such anti-Buddhist connotations in the Engishiki as the salient features of traditional Shintō ritualism. Takatori, however, pointed out that they probably originated in a very specific context, namely the so-called Dōkyō Incident of the late 760s. At that time, Dōkyō (700-772), a high ranking Buddhist monk and advisor to the female sovereign Shōtoku (718-770; r. 749-758 under the name Kōken, and 764-770 as Shōtoku) almost succeeded in making himself emperor. According to Takatori, it was only in reaction to this infamous attempt to establish a Buddhist theocracy that the court nobility systematically excluded Buddhists from certain leading functions in order to protect their traditional hereditary

23 Engishiki, vol. 5; cited from Bock, 152-153. The first mention of such taboo words can be found in the Kōtaijingū gishikichō, a set of rules for the Inner Shrine of Ise from 804. 
prerogatives. ${ }^{24}$ If Takatori is correct, then the identification of Buddhism with defilement was not a "natural" grass-roots reaction against an alien religion, but rather a top-down measure initially caused by competing ritualists at court. Similarly, the preoccupation with purity and defilement in relation to death, and in particular with vengeful spirits, seems to have started within the court aristocracy in the period following the Dōkyō incident from top down rather than from bottom up.

\section{Buddhist Management of the Death Taboo}

According to famous Buddhist theologians such as Hōnen (1133-1212), the founder of the Japanese Pure Land school (Jōdo-shū), ${ }^{25}$ "in the Buddhist teachings, there is no such thing as avoidance, as it is commonly spoken of in the world". ${ }^{26}$ In an insightful article on Japanese death taboos, the American scholar of Japanese religion Jacqueline Stone qualified this statement in the following way:

In formal Buddhist doctrine, pollution has little place, except, perhaps, as metaphor: an awakened mind is said to be 'pure', while a deluded mind is 'defiled'. Similarly, the realm of a buddha or bodhisattva, being free of delusion and suffering, is called a pure land (jōdo), while a realm inhabited by ordinary deluded beings such as our present, Sahā world, full of greed, hatred, and ignorance, is called a defiled land (edo). In the sphere of ethical and ritual practice, however, monastic Buddhism in particular has its own standards of 'pure conduct', such as refraining from killing living beings and abstaining from eating meat or pungent roots, drinking alcohol, and engaging in sexual activity. ${ }^{27}$

In other words, Japanese Buddhists knew of and paid attention to the above-mentioned pollution caused by death. However, they treated such issues differently from the court society's lay members. This is most clearly reflected in a genre of short didactic tales (setsuwa) of Buddhist origin. The following example can be found in two setsuwa collections, and is set in roughly the same period as the previous example of Empress Anshi. A family from the lower nobility in the capital encounters a problem in getting the body of their deceased father to the graveyard, since the gate of their precinct happens to be in an "ill direction," according to Yin Yang principles. Their elderly neighbor, a former palace guard who has become a

24 Takatori, Shintō no seiritsu, 37-63; Mori, "Ancient and Classical Japan," 55.

25 The concept of "Pure Land" (Skt. sukhāvatī, Jap. jōdo) usually refers to a kind of paradise by a specific Buddha and is a typical product of Mahayana Buddhism. In Japan, it was intimately related to the belief in Buddha Amitābha (Jap. Amida) and led to the creation of a distinct school by Hōnen and his followers, which differed from all other Buddhist denominations in many respects, for instance, in the observance of celibacy. Jōdo-shū and its offshoot Jōdo Shinshū are nowadays the strongest factions within Japanese Buddhism.

26 Stone, "Do Kami Ever Overlook Pollution?," 211.

27 Stone, "Do Kami Ever Overlook Pollution?," 207. 
Buddhist lay monk, offers them the possibility of carrying the corpse through his own precinct. The lay monk's family protests:

Even the saintliest holy man [...] would hardly do this kind of thing. Who ever heard of anyone with so little care for his own safety that he lets his neighbor's dead body be taken out of his gate? ${ }^{28}$

As the story makes clear, the family expects immediate trouble with unseen forces resulting from coming into contact with death pollution. The lay monk, however, dismisses their objections and permits the passage of his neighbor's dead body. As a Karmic reward for his courageous and compassionate action, he reaches a lifespan of over ninety years, and, despite their initial doubts, his family members thrive as well.

The interesting point of this story is that taboos from outside Buddhism, in this case related to Yin and Yang, but also to death, are not rejected outright. The text presents the conflict between directional taboos and death taboos as a serious problem. Within this framework, the lay monk exhibits extraordinary human compassion, and in this case Karmic reward overrules the "natural" consequences of breaking a death taboo. In other words, sincere Buddhist virtue can ward off death pollution. Nevertheless, death taboos have to be taken into account even though they do not belong to Buddhism in a strict sense.

Death pollution even mattered in the case of kami who functioned as guardians of Buddhist temples, such as Sannō Gongen, the protector deity of Tendai Buddhism. Tendai's central monastic complex is situated on Mt. Hiei, to the northwest of Kyoto. At the foot of the mountain is a shrine dedicated to Sannō, which is actually a collective name for three main and many lesser protector deities. Although many of these deities are of Indian origin and the whole shrine compound gained prominence only after a monastic complex was established in its vicinity by the Japanese Tendai patriarch Saichō (767-822), the deities are regarded as kami and therefore require a ritual and spatial separation from proper Buddhist temples. ${ }^{29}$ Such separation notwithstanding, Ryōgen (912-985), a major reformer of Hiei monasticism, included worship of Sannō in a set of 26 monastic rules that he wrote in 970 . Rule 23 states that every monk on Mt. Hiei must attend sūtra chanting cere-

28 Konjaku monogatari-shū, vol. 20, tale 44; Uji shūi monogatari, tale 24; trans. Mills, A Collection of Tales from Uji, 171-172.

29 Today the site is known as Hiyoshi Shrine, located in Sakamoto at the shores of Lake Biwa. On the development of the shrine originally known as Hie, see Breen and Teeuwen, A New History of Shinto, chapter 3. The name of Sannō, lit. "mountain king”, was introduced by Saichō, whose biography is intimately connected to the original deities of Hie. Saichō adopted the name Sannō from a Chinese deity by the same name, which was worshiped as the protector of Guoqing si, the head temple of Chinese Tiantai (Jap. Tendai), where Saichō received his training in Tendai teachings (Breen and Teeuwen, A New History of Shinto, 77). This indicates that the combined worship of Buddhist and native deities was not specific to Japanese Buddhism. 
monies for Sannō, which were to be held twice a year. ${ }^{30}$ Absence was permissible only "if a monk is sick, has become ritually defiled, or is invited to an official or private service" 31 at court. Due to this provision, Ryōgen himself had to miss the Sannō sūtra chanting in 973 because it happened to occur within the 30-day mourning period after a funeral service (see the Engishiki rules above) that Ryōgen had performed for his patron, Fujiwara no Koremasa (924-972). However, during this period he left the mountain and unintentionally passed through the precincts of the Sannō Shrine. He feared to have incurred a curse (tatari) by Sannō as a result and drafted a written apology to the kami, from which we know of these events. ${ }^{32}$

This demonstrates that kami like Sannō were regarded as supporters of Buddhism and received mass rituals of sūtra chanting. In fact, they were even explained as manifestations or "traces" (suijaku) left on earth by former "original buddhas" (honji) in order to sustain human beings. ${ }^{33}$ Nevertheless, they were also regarded as proper native deities likely to react negatively to pollution, and in this sense as lying outside of Buddhist control and doctrine. As the Buddhist reformer Nichiren (12221282) put it, a few centuries after Ryōgen:

Japan is the land of the kami (shinkoku). And it is the way of this country that, in many cases, strangely enough, the manifest traces (suijaku) of the buddhas and bodhisattvas [i.e., the kami] do not conform to the sūtras and treatises, and when one goes against them, there is actual punishment. [...] Those born in this country would do well to observe their prohibitions! ${ }^{34}$

\section{Defilement in the Shintō-Buddhist Pantheon}

As shrines for Sannō and other Buddhist kami indicate, the distinction between native deities and deities from other cultural spheres, in particular the Indian deities brought to Japan by Buddhist lore, was often blurred. Local kami and Indian devas existed in the same pantheon and were receptive to Buddhist rituals. It seems, however, that the implicit social hierarchy that identified "pure" with high and "defiled" with low social status was transferred also to this syncretic pantheon. This, at least, is suggested by the following story, once again from the setsuwa genre. The tale is the first in a collection called Uji shūi monogatari ("Tales Gleaned from [the collection of] Uji”) compiled around 1200, which is mostly dedicated to Buddhist topics but presents them with a distinctly humorous gist.

30 Groner, Ryōgen and Mount Hiei, 238, 363.

31 Groner, Ryōgen and Mount Hiei, 363.

32 Stone, "Do Kami Ever Overlook Pollution?," 209.

33 On the concepts of honji and suijaku, cf. Teeuwen and Rambelli, eds., Buddhas and Kami in Japan, 2003.

34 Gassui gosho; cited from Stone, "Do Kami Ever Overlook Pollution?,” 226. 
The main protagonist of this tale is the Buddhist monk Dōmyō (974-1020), another historical figure from classical court culture who gained fame as a poet and as a master of chanting the Lotus Sūtra. While other setsuwa recount all manner of miracles connected to his chanting skills, the Uji shüi reveals some of his human weaknesses, particularly as they related to his romantic relationship with Izumi Shikibu (970-?), herself a legendary poetess and a stunning beauty. ${ }^{35}$ One night, so the story goes, Dōmyō had sex with her and subsequently turned to his chanting routine.

By the time he had chanted all eight books [of the Sūtra], it was near daybreak. He was just about to doze off, when he sensed someone nearby. 'Who is it?' he asked and the answer was, 'I am the old man from around Fifth Avenue and Nishi-no-Tōin Lane.' - 'What do you want?' 'I have been listening tonight to your chanting of the Sūtra, and I shall in all my lives to come never forget it.' - 'But I chant the Sūtra regularly. What was so special about tonight?' To this the roadside deity (sai) of the Fifth Avenue replied: 'At times, when you deign to chant the Sūtra in a purified state (kiyokute), [all the gods] beginning with Brahma and Indra come to listen and it is impossible for an old man like me to approach you. Tonight, since you chanted without making the water ablutions, I caught a moment when Brahma and Indra were not present and got the unforgettable chance to listen to you. ${ }^{36}$

While most modern readers will smile in sympathy with the lowly god in the guise of an old man, the comment at the end of the story emphasises a different aspect:

Therefore one must perform purification, even when chanting at a trifling occasion. As the venerable Eshin ${ }^{37}$ said, 'never chant the Buddha name (nenbutsu) or the Sūtra without paying attention to the Four Rules [of proper conduct as a monk].38

This commentary implies that the encounter with a roadside deity was a humiliating experience for an aristocratic cleric. Roadside deities (generally known as dōsōjin or sai/sae no kami) seem to have played a role in agricultural fertility rites and were frequently represented in the form of loving couples or phallic stones. ${ }^{39}$ The story obviously draws a tacit connection between Dōmyō's sexual adventures and the

35 Dōmyō was in fact another scion of the Fujiwara and studied as a child under the abovementioned Tendai abbot Ryōgen on Mt. Hiei. On the corpus of legends about his relationship with Izumi Shikibu, which include even the motif of incest, see Marra, Representations of Power, 96-99.

36 Uji shūi monogatari, tale 1. My translation is indebted to Mills, A Collection of Tales from Uji, 135136, and Japanese Tales, trans. and ed. Tyler, 258; emphasis is mine.

37 Genshin (942-1017; also known as Eshin Sozu), a Tendai monk and precursor of the Pure Land movement.

38 Jap. shi igi, rules referring to the four actions of walking, standing, sitting, and lying.

39 The first Japanese dictionary, the Wamyō ruijusho from the tenth century, defines dōsojin (lit. ancestor gods of the roads; roadside deities) as sae no kami, "deities of prevention". The first descriptions of such deities seem to be contained in the Fusō ryakki, a history of Japan by an anonymous monk from the late Heian period. It classifies roadside deities as "strange figures" and describes them as male-female couples with visible sexual organs (Czaja, Gods of Myth and Stone, 4445). Later examples, mostly from the early modern period, show dressed couples sometimes embracing each other in sexual union. Such couples are at times carved on the figure of a phallus. 
fact that a "sexual deity" listened to him. While his motivation to chant the sūtra immediately after his sexual encounter with Izumi Shikibu is not explained in the text, it is possible that medieval readers understood it as an attempt to counterbalance the negative Karmic retributions resulting from his transgression of celibacy. The commentary, however, seems not particularly concerned about this breach of monastic rules. Instead, it highlights the fact that Dōmyō neglected the proper ritual preparations before chanting the Lotus Sütra. It becomes apparent that such preparations are necessary for addressing the "aristocracy" among the gods, while the common people's deities do not pay attention to such things. Consequently, Dōmyō's pious efforts were not only in vain, but on top of that were exploited by a god who was himself rather an outcast. The commentary, therefore, seems to suggest that the roadside deity by his very presence defiled the noble chanting. In any event, chanting for a roadside deity did not improve Dōmyō's Karmic balances.

The story further reveals that from a Buddhist angle, devas from India and native kami are united in a world without ethnic boundaries but with a strict social hierarchy. ${ }^{40}$ As noted above, non-Buddhist deities were often interpreted as "traces" left by Buddhist entities (and thus ultimately as "didactic means" [upāya; Jap. hōben]). Yet at the same time, the deities mirror the human world in that they strive for Buddhist salvation and seek to avoid ritual defilement, especially if they belong to the higher echelons of the pantheon. Purity in the classical period thus seems to have functioned as a marker of social distinction even in the world of the unseen. It was not, however, an ethnic marker of the native pantheon, as traditional interpretations of Shintō would have us believe.

\section{Shintō Attempts to Regain the Realm of Death}

These setsuwa may suffice to demonstrate that the taboos set up against Buddhism in the Engishiki had lost most of their relevance already by the end of the classical period. The taboos against death, however, remained intact, particularly in a Shintō context. This is illustrated in a striking story about a Shintō priest's death. It is set once again in the environment of the imperial court, but during the medieval period, when political power in Japan had shifted to the shōgun (military governor) and the emperor's court was reduced to largely ceremonial functions. At that time,

40 The Konjaku monogatari contains a story which makes a similar point. An anonymous "Dharma protecting deity" of Japanese origin is unable to fulfil his promise and offer food to a pious monk when another monk recites the Lotus Sütra with him. The reason is that the Lotus Sütra attracts the attention of "Brahma, Indra, the Four Deva Kings and the Holy Throng of Bodhisattvas who guard the Lotus Sutra" (Tales of Times now Past, trans. Ury, 92), whose presence prevents the local god from approaching the monks (Konjaku monogatari shū, 13, tale 39). 
a court priest called Yoshida Kaneatsu (1368-1408) wrote a detailed account of his father's death in his diary.

We learn that Kaneatsu's father, in spite of his function as the head of the Yoshida Shrine in Kyōto, wanted to take Buddhist orders when he felt his end coming, as was common amongst members of the nobility shortly before their death. In order to do so, he had to ask for the shōgun's permission. The permission was granted and Kaneatsu's father took the status of a lay monk. On his deathbed he chanted the nenbutsu (Buddha Amida's name) and thus entered the Pure Land. His son and the rest of the family, however, could not stay with their dying father due to the particularly severe taboos against death pollution, which governed the world of Shintō priests. This prompts Kaneatsu to lament in his diary: "The state of a Shintō priest is indeed powerless!" 41 This example illustrates that during the Japanese medieval period even high-ranking Shintō priests would seek Buddhist salvation and yet observed a strict regime of non-Buddhist taboos. Yoshida Kaneatsu, however, was obviously critical of this state of affairs and realised that it limited his religious capacities.

About one hundred years later, Yoshida Kanetomo (1435-1511), a member of the same priestly family, devised a systematic teaching that functioned theoretically without Buddhism and also included a kind of funeral ritual. This was in fact the first systematised form of Shintō that overcame the traditional division of labor between shrines and temples. ${ }^{42}$ Yoshida Shintō even developed visions of the afterlife that enabled them to conduct funeral rites, which included deification of the deceased. ${ }^{43}$ With the diffusion of Yoshida Shintō, particularly during the Tokugawa period (1600-1868), Shintō funerals became an option, and death pollution could be overcome (in theory at least) by non-Buddhist ritual means.

Nevertheless, the official religious policy of the Tokugawa Shogunate rather privileged Buddhism in that it made Buddhist funerals more or less obligatory for the entire populace. ${ }^{44}$ This led to the curious fact that Buddhism concentrated all its efforts on its monopoly on death ritual, while the intellectual avant-garde became increasingly critical of Buddhist doctrines. When the Tokugawa regime eventually declined in the early nineteenth century, such criticism was taken over by parts of the general populace. Consequently, the coup d'état of 1868 (the Meiji Restoration) led not only to the official disentanglement of Shintō and Buddhism (shinbutsu bunri), but also to a short but violent phase of anti-Buddhist violence. ${ }^{45}$ At that time it seemed that Shintō might become a kind of state religion backed by the newlyformed Meiji government. By about 1880, however, the government had reduced

41 Yoshida-ke hinamiki, 1402/4/26; Scheid, Der eine und einzige Weg der Götter, 95-98; Scheid, “Overcoming Taboos on Death," 211-212.

42 For a general outline of Yoshida Shintō, see Scheid, Der eine und einzige Weg der Götter.

43 Bernhard Scheid, “'May the Leaves and Twigs of my Descendants Bloom Forever', 321-338.

44 Hur, Death and Social Order in Tokugawa Japan.

45 Ketelaar, Of Heretics and Martyrs in Meiji Japan. 
Shintō shrines to mere places of emperor worship and even forbade Shintō funerals. As a consequence, the traditional "division of labor" continued largely unchanged until the present day: Shintō shrines are places for this-worldly concerns and auspicious festivals like the New Year; Buddhist temples have their economic basis and spiritual raison d'être in services for the dead. Even notions of death pollution remain current in modern society, as demonstrated, among other things, by a number of smaller taboos. These include refraining from shrine visits and seasonal greetings at New Year if there has recently been a death in the family, or the purification with salt when returning from a funeral. The faint association of Buddhism with death pollution can even be observed in the case of kitamakura, lit. "northern pillow". This refers to the custom to turn the head of a dying person to the north, in imitation of the death of the Buddha. Due to this custom, it is generally regarded as a taboo in everyday life to sleep with one's head pointing north.

\section{Death Taboos and the Coexistence of kami and Buddhas}

In conclusion, let me try to summarise the findings of my brief historical sketch of Japanese death taboos in a more abstract way in order to show why I regard these taboos to be the "common matrix of Buddhism and Shintō".

If we go back to the early classical period, we can say that courtly Shintō - or rather the world of courtly kami ritualists, including the emperor, who is himself seen as a kami - created a twofold universe of pure and defiled, placing itself in the pure part only. The higher their rank, the more a person had to be protected from potentially defiling contacts. Defilement, however, was regarded as a consequence of the most natural physiological actions, such as birth and death. Impurity was therefore being constantly re-established by people being born or dying. The disintegration of the body, including traces of blood or signs of illness, offended the kami and made people vulnerable to attacks by vengeful spirits. Conversely, negative events, such as natural catastrophes or epidemics, were explained as the reactions of kami and spirits who had been offended by pollution.

While crimes and moral transgressions also constituted causes of defilement, the question whether such causes were produced intentionally or not did not make much difference according to the logic of taboo regulations. Thus women in labor or people in mourning were sources of pollution despite having done no moral evil to their environment. In this respect, taboo regulations differed strikingly from Buddhist moral conceptions, such as the theory of Karmic retribution. For this reason, traditional views of Japanese religion tended to regard such taboos as salient, transhistorical features of "Shintō" and at the same time as natural reactions against Buddhism. Takatori and others argued, however, that the death taboos varied ac- 
cording to time and space, coming into existence at a time when Buddhism was already established in Japan. Moreover, if death taboos were indeed the domain of Shintō only, one would expect Buddhist theology to have developed counter-theories. Japanese Buddhists, however, hardly ever criticised the fear of death pollution (with the exception of some radical zealots of Amitābha's Pure Land). Instead, Buddhist monks incorporated the notions of pure and defiled, together with faith in the kami, into their own religious system. Centres of Buddhist learning felt in need of spiritual protection and singled out local kami for this task or invented new ones. Thus, Buddhist kami shrines that were both modelled after, and integrated into, the system of imperial kami ritualism came into existence. Consequently, even Buddhist kami acted according to non-Buddhist concepts of pollution and purification. In other words, Japanese Buddhist institutions supported religious practices and ways of thinking that contradicted the basic morality of Buddhism.

The systems of taboo and avoidance, on the one hand, and of Karmic retribution, on the other, existed too long side by side to be regarded as a weak compromise. Rather, I would argue that their coexistence was stable because Japanese Buddhism - which was the only institution in Japan which developed a monastic organisation independent of the state - profited from it. While taboos and defilement known as kegare presupposed the existence of kami who defined what was pure and what was defiled, Buddhists had the power to appease irritated kami due to their access to the higher echelons of the pantheon where the buddhas resided. Buddhism could therefore present itself as the most effective institution able to get rid of death pollution and evil spirits. ${ }^{46}$ This is, in my view, a major reason why Japanese Buddhists never produced a fundamental critique of kegare but instead reinforced these taboo laws, inexplicable as they were. Of course, Karmic retribution and reward which became increasingly visualised in the realms of hell and paradise (Pure Land), were always strong arguments for why Buddhism mattered. Yet the afterlife scenarios of hell, paradise and other realms of rebirth have nothing to do with the defilement caused by death in this world. In this sense, Shintō deities are this-worldly agents that delineate the boundaries between pure and defiled, which only Buddhist specialists can cross unharmed. The kami thus explain why Buddhism matters in one's present life (removing defilement and the threats by the spirits of the dead), while the concept of Karma explains why Buddhism matters in one's afterlife.

Seen from this angle, it becomes clear that kegare is of equal importance for both Buddhism and the realm of the kami which we now call Shintō. Japanese Buddhism was sustained not only by its own doctrines, but also by non-Buddhist rites of avoidance and taboos related to death, even if the ideas from which such ritual

46 Alternative specialists such as masters of Yin and Yang (onmyōji) existed in classical Japan, but their status gradually declined while their concepts were absorbed into Buddhism and the incipient schools of Shintō during the medieval period (see, for instance, Hayashi and Hayek, eds., Onmyōdō in Japanese History). 
derived contained some anti-Buddhist potential. This interlocking of Buddhist and non-Buddhist concepts is probably a major reason for two particular characteristics of Japanese religious history: the dominant role of Buddhism when compared to, for instance, China or Korea, and the remarkable stability in the coexistence of kami and buddhas.

\section{Bibliography}

\section{Primary Sources}

Eiga monogatari ("A Tale of Fame and Fortune", eleventh century). Translated by William H. McCullough and Helen Craig McCullough, A Tale of Flowering Fortunes: Annals of Japanese Aristocratic Life in the Heian Period. Stanford University Press, 1980.

Engishiki ("Procedures of the Engi Era", 926), 5 vols. Translated by Felicia Bock, Engi-Shiki, Procedures of the Engi Era, 4 vols. Tokyo: Sophia University, 1970.

Fusō ryakki ("Short History of Japan", eleventh or twelfth century)

Gassui gosho ("Letter on Moonwater [Menstruation]", Nichiren, 1264).

Konjaku monogatari-shü ("Tales from Times Past”, tenth century). Partly translated by Marian B.

Ury, Tales of Times now Past: Sixty-Two Stories from a Medieval Japanese Collection. Berkeley:

University of California Press, 1985.

Kōtaijingū gishikichō (“Protocols of Inner Shrine Rituals”, 804)

Nihon shoki ("Annals of Japan", 720). Translated by William George Aston, Nihongi: Chronicles of Japan from the Earliest Times to A.D. 697. London: Kegan Paul, 1896.

Shōyūki (Diary of Fujiwara no Sanesuke [957-1046])

Uji shūi monogatari (“Tales Gleaned from the Uji Collection", twelfth century). Translated by Mills, Douglas E., A Collection of Tales from Uji: A Study and Translation of Uji Shūi Monogatari. Cambridge University Press, 1970.

Yōrō ritsuryō ("Penal and Administrative Code of the Yōrō Era”, 757), vols. 2-10. Translated by Hans A. Dettmer, Der Yōrō-Kodex. Die Gebote. Übersetzung des Ryō no gige, Teil 2, Bücher 2-10. Wiesbaden: Harrassowitz Verlag, 2010.

Yoshida-ke hinamiki (unpublished diaries from Yoshida Kanehiro and Yoshida Kaneatsu, fourteenth - fifteenth centuries, stored at Tenri University Library)

Wamyō ruijusho ("Dictionary of Japanese Words", 930s)

\section{Secondary Literature}

Breen, John and Mark Teeuwen, eds. Shinto in History: Ways of the Kami. London: Curzon, 2000. Breen, John and Mark Teeuwen. A New History of Shinto. Malden/Mass., Oxford: Wiley-Blackwell, 2010.

Czaja, Michael. Gods of Myth and Stone: Phallicism in Japanese Folk Religion. New York: Weatherhill, 1974.

Farris, William W. Population, Disease, and Land in Early Japan, 645-900. Cambridge/Mass.: Harvard University Press, 1985. 
Farris, William W. Japan's Medieval Population: Famine, Fertility, and Warfare in a Transformative Age. Honolulu: University of Hawai'i Press, 2006.

Faure, Bernard, Michael Como, lyanaga Nobumi, ed., Rethinking Medieval Shintō. Cahiers d'Extrême-Asie 16. Kyoto: École française d'Extrême-Orient, 2009.

Groner, Paul. Ryōgen and Mount Hiei - Japanese Tendai in the Tenth Century. Honolulu: University of Hawai'i Press, 2002.

Hayashi, Makoto and Matthias Hayek, eds. Onmyōdō in Japanese History. Vol. 40/1, Japanese Journal of Religious Studies. Nagoya: Nanzan Institute for Religion and Culture, 2013.

Hur, Nam-lin. Death and Social Order in Tokugawa Japan. Cambridge/Mass.: Harvard University Press, 2007.

Ketelaar, James. Of Heretics and Martyrs in Meiji Japan: Buddhism and Its Persecution. Princeton University Press, 1990.

Kuroda, Toshio. "Shinto in the History of Japanese Religion," trans. James C. Dobbins and Suzanne Gay. Journal of Japanese Studies 7, no. 1 (1981): 1-21.

Marra, Michele. Representations of Power: The Literary Politics of Medieval Japan. Honolulu: University of Hawaii Press, 1993.

Mori, Mizue. “Ancient and Classical Japan: The Dawn of Shinto.” In Shinto - A Short History, edited by Inoue Nobutaka, Ito Satoshi, Endo Jun, Mori Mizue, translated by Mark Teeuwen and John Breen, 12-62. London, New York: Routledge Curzon, 2003.

Ooms, Herman. Imperial Politics and Symbolics in Ancient Japan: The Tenmu Dynasty, 650-800. Honolulu: University of Hawai’i, 2009.

Scheid, Bernhard. Der eine und einzige Weg der Götter: Yoshida Kanetomo und die Erfindung des Shinto. Vol. 38, Beiträge zur Kultur- und Geistesgeschichte Asiens. Vienna: Verlag der Österreichischen Akademie der Wissenschaften, 2001.

Scheid, Bernhard. "Overcoming Taboos on Death: The Limited Possibilities of Discourse on the Afterlife in Shinto." In Practicing the Afterlife: Perspectives from Japan. Sitzungsberichte der phil.-hist. Klasse 713. Vol. 42, Beiträge zur Kultur- und Geistesgeschichte Asiens, edited by Susanne Formanek and William LaFleur, 205-230. Vienna: Verlag der Österreichischen Akademie der Wissenschaften, 2004.

Scheid, Bernhard. “"May the Leaves and Twigs of my Descendants Bloom Forever.' Posthumous Deification among Political Rulers in Pre-Modern Japan." In Death at Court, edited by Karl-Heinz Spieß and Immo Warntjes, 321-338. Wiesbaden: Harrassowitz, 2012.

Stone, Jacqueline I. "Do Kami Ever Overlook Pollution? Honji suijaku and the Problem of Death Defilement.” Cahiers d'Extrême-Asie 16 (2006-2007): 203-232.

Strickmann, Michel. Chinese Magical Medicine. Stanford University Press, 2002.

Takatori, Masao. Shintō no seiritsu (“The Formation of Shintō”). Tokyo: Heibonsha, 1979.

Teeuwen, Mark. "From jindō to Shinto: A Concept Takes Shape." In Tracing Shinto in the History of Kami Worship, edited by Mark Teeuwen and Bernhard Scheid, 233-263. Japanese Journal of Religious Studies 29, no. 3-4. Nagoya: Nanzan Institute for Religion and Culture, 2002.

Teeuwen, Mark and Bernhard Scheid, ed. Tracing Shinto in the History of Kami Worship. Japanese Journal of Religious Studies 29, no. 3-4. Nagoya: Nanzan Institute for Religion and Culture, 2002.

Teeuwen, Mark and Fabio Rambelli, ed. Buddhas and Kami in Japan: Honji Suijaku as a Combinatory Paradigm. London, New York: Routledge Curzon, 2003.

Tyler, Royal, trans. and ed. Japanese Tales. New York: Pantheon Books, 1987. 
